\title{
The urgency of Academic Culture Development as Reinforcement of Character among Students
}

\author{
Daniel Harapan Parlindungan Simanjuntak ${ }^{1}$, Payerli Pasaribu ${ }^{2}$, Waston Malau ${ }^{3}$ \\ \{danielhp@unimed.ac.id ${ }^{1}$, payerlipasaribu@unimed.ac.id ${ }^{2}$.wastonmalau@unimed.ac.id ${ }^{3}$ \} \\ 1,2,3 Universitas Negeri Medan, Medan, North Sumatera, Indonesia
}

\begin{abstract}
This article is an article that seeks to illustrate to readers and educators, in general, the importance of cultural mapping in strengthening the character of their students. Character Enforcement is the key to success in creating a better future. While the development of academic culture is one of the efforts in strengthening character. Academic culture is rarely a concern in academic studies in universities. If there were any, then not many of the studies have been followed up. Academic culture is related to scientific attitudes such as the intended scientific attitude, curiosity, critical attitude, open attitude, objective attitude, willingness to respect the work of others, the courage to defend the truth, and attitude to reach forward. Mapping academic culture is expected to provide an overview of lecturers and study programs in developing learning strategies and strengthening student character.
\end{abstract}

Keywords: Academic culture, Developing learning strategies, Character.

\section{Introduction}

Six assignments in the KKNI (KKNI is a term used for the curriculum used at Universitas Negeri Medan) curriculum implemented by Universitas Negeri Medan since 2016 seem to be a problem for students. Research conducted in 2017 shows that students experience obstacles in completing assignments given to them [1]. The quality of assignments collected by students is an issue that needs attention. Based on preliminary observations of this study on the results of six assignments in each course, the Research Team found unfavorable results. This can be seen from the grades obtained by students in each assignment. The quality of student assignments is greatly influenced by the scientific attitude of each student. A scientific attitude must be present in a student when facing scientific problems. The scientific attitude in question is a curious, critical, and open attitude, an objective attitude, an attitude of willingness to respect the work of others, an attitude of courage to defend the truth, and an attitude of reaching out to the future [2]. The development of scientific attitudes can shape academic culture.

Scientific attitudes become one of the assets for students as the next generation of the nation in achieving a better future. Attitudes that are implanted are expected to be the character of the nation's future generations. Therefore the formation of academic culture must be a joint effort to improve the quality of graduates of study programs in tertiary institutions. The said effort must be carried out through various activities that directly involve students. Learning is one of the activities that directly involve students. The implementation of good learning starts with planning the implementation of good learning as well. 
Academic culture will develop if there are: (1) Objective appreciation of other people's opinions; (2) Rational and critical-analytical thinking with moral responsibilities; (3) Reading habits; (4) Addition of knowledge and insight; (5) The habit of researching and serving the public; (6) Writing articles, papers, books; (7) Scientific discussion; (8) teaching-learning process; and (9) Good university management [2]. These nine things are factors that influence the development of academic culture. These factors must be considered seriously to form an academic culture in students. The formation of academic culture is not only the responsibility of university leaders but all elements of the university. The study program is one element in a college. The Anthropology Education Study Program is an educational study program that is expected to produce high-quality Anthropology-Sociology and Social Sciences teacher candidates who can meet the needs of the era. As one of the elements in Medan State University, the Anthropology Education Study Program is responsible for assisting the formation of academic culture.

Higher education is a field where intellectual candidates are born for the future of the nation. So that positive values such as honesty, smart, caring, tough, responsibility, religious and other positive values can be instilled, internalized, and become a culture to build intellectual traditions. The main values of these characters are the main supporters in the process of creating an academic culture [3]. Academic culture can also be interpreted as a universal culture that should be owned by every student by involving himself in academic activities. Academic culture should be inherent in all college academics, be it, lecturers or students. Because academic culture also refers to the way of life of a pluralistic and multicultural scientific community that is sheltered in an institution that bases itself on the values of scientific truth and objectivity.

The characteristics of the development of student academic culture, can be seen from the development; (1) Reading habits and the addition of knowledge and insights, (2) Writing habits, (3) Scientific discussions, (4) Optimization of student organizations, (5) Teaching and learning process [3]. This research is intended to map the academic culture of students in the Anthropology Education study program environment. Reading habits and the addition of knowledge and insights are used as characteristics of the existence of academic culture among students. Reading habits can be seen from the many types of books read by students. Student reading habits will certainly relate to the ease of access for students to get books both electronic and printed books. Reading habits are also related to the addition of knowledge and insight of students. The indicator used to see the addition of students' knowledge and insight is through responding both verbally and in writing from students to various phenomena related to the course being attended. The intended writing habit is the habit of writing scientific articles published in journals or other media. Writing habits are related to reading habits, access, and writing habits themselves.

Writing access is closely related to the internet network, equipment owned, writing themes or topics, and how often students are given writing assignments. Scientific discussion is one of the activities that reflect the development of academic culture among students. This activity should be a forum for students to develop reasoning and scientific tolerance. Scientific discussion can be related to reading, writing, teaching and learning activities and optimizing student organizations through various activities. The optimization of student organizations through various activities becomes an inseparable factor in the development of academic culture among students. Student Association Departments or Study Programs and Student Activity Units can be involved in efforts to develop an academic culture among students. Another feature that is also strongly associated with the development of academic culture among students is the teaching and learning process. Teaching and learning processes that 
encourage the growth of the academic culture. Each course has the same role in shaping academic culture because this business is a joint and systematic effort. Systematic means that the characteristics of the development of academic culture among students must become interrelated with one another. Some academic attitudes that reflect the academic culture in Universitas Negeri Medan include critical attitude, open attitude, objective attitude, the attitude of respect for the work of others, an attitude of curiosity, an attitude of maintaining the truth. This study will map academic culture based on the intensity of students in carrying out six academic attitudes. The researcher determines several indicators of each attitude in the academic culture. The indicators are then used as a basis for preparing the questionnaire.

Indicators of critical attitude are the intensity of asking about the topic being discussed at the lecture, giving an opinion on the views of others, and providing personal analysis in the tasks of the CBR and CJR. Open attitude indicators include: accepting input or criticism from other parties about their views, accepting the ideas or ideas of others, and being willing and able to collaborate with others. Objective attitude is shown in the following indicators: acknowledging mistakes and weaknesses in completing tasks that result in the acquisition of low grades, doing the task according to instructions, and doing individual tasks to the maximum. Attitude to respect the work of others is shown by integrity and not plagiarism in completing tasks. Indicators of curiosity will be demonstrated by always reading lecture contracts and course RPS, preparing before learning begins by reading various sources related to the topic being discussed, asking questions during the lecture hours, and reading books related or not related to the course taken. Finally, indicators of attitudes to defend the truth are shown by the intensity of delivering statements under the truth (telling the truth), not cheating, and obeying lecturer contracts.

\section{Methods}

This study uses a descriptive qualitative research method with the approach of Phenomenology Edmund Husserl. To observe the conceptual phenomena of the subjects observed through their actions and thoughts to understand the meaning arranged by the subjects around everyday events.[4] This phenomenological approach requires the unification of research subjects with supporting subjects and research objects. Phenomenology is not just a direct experience, but an experience that has implicitly interpreted the work/interpretation. The location of this research is the Study Program Anthropology Education in Faculty of Social Sciences Universitas Negeri Medan. The choice of location is based on that social science generally requires students to be more active in reading, discussing, writing, and other academic cultures when compared to natural science. the study program of Anthropology Education that deals with social and cultural phenomena.

The research informants were determined purposively, namely students of 2017 in the Anthropology Education Study Program. The selection of participants who come from students is based on consideration, the longer a person is in a social environment, the stronger the internalized understanding within him will then greatly influence the actions he will take. Data collection is done through simple surveys, observations, interviews, and documentation. The collected data is classified, categorized, interpreted, and then analyzed. The analysis is used by using the concepts of various views arranged in a theoretical framework so that finally able to create conclusions following the actual conditions occurring in the field. Through narrative description will be described how social phenomena with the interpretation and interpretation of researchers. 
Questionnaires were distributed to 50 students out of 100 active students in the third semester. All students who were respondents were chosen to take courses that were influenced by the research team. This is intended to obtain an objective survey and observation data because the research team directly observes every activity needed to see attitudes related to academic culture. Data from the questionnaire is then tabulated and the percentage is used to obtain behavioral tendencies that are used as a basis for mapping academic culture. The results of the questionnaire data processing will be compared with the observation data for interpretation of the data, which in the end will be concluded.

\section{Finding and discussion}

\subsection{Critical attitude and curious}

Researchers distributed questionnaires to 50 students consisting of 17 men and 33 women. Questions about the intensity of student habits in several ways, namely: the habit of asking about the topic being discussed during lectures, the habit of giving opinions to the views of others, and the habit of providing personal analysis in CBR and CJR assignments. The answers of the fifty respondents in the simple survey can be seen in Table 1 below:

Table 1. Average of Critical Attitude

\begin{tabular}{lccc}
\hline & & \multicolumn{2}{c}{ Critical Attitude } \\
\cline { 2 - 4 } Gender & Never & Often & Constantly \\
Male & 6 & 8 & 3 \\
Female & 8 & 14 & 11 \\
\hline
\end{tabular}

Resource: Field Research, 2019

Table 1. above shows that students with female gender have more critical attitudes $(33.33 \%)$ compared to students who are male $(27.27 \%)$. Overall students have a critical attitude of $28 \%$ thus it can be stated a critical attitude of students based on overall respondents is still low. Some things that students must have to be able to be critical are knowing things such as (a) which are actually real issues, problems, or decisions taken into consideration, (b) the focus of the problem, (c) rational to solve the problem and whether the rationale is true, (d) the assumptions used as the basis, (e) the method of presentation is clear, (f) the conclusion is correct, and $(\mathrm{g})$ the implications are clear [5].

The low critical attitude of students can be caused by several factors, based on the results of interviews some factors cause the low critical attitude of students. The factor is students lacking or not mastering the topic being discussed. Mastery of the topic being discussed can be caused by a lack of information related to the topic. Topics can be mastered if students have information on the topic being discussed. This can be done by getting used to reading various sources related to the topic being or will be discussed in the meeting every week. The results of this critical attitude survey are confirmed from the results of the following survey of curious attitudes.

Table 2. Average of Curious Attitude

\begin{tabular}{llll}
\hline Gender & Never & Often & Constantly \\
\hline
\end{tabular}




\begin{tabular}{cccc}
\hline Male & 10 & 4 & 3 \\
Female & 11 & 12 & 10 \\
\hline
\end{tabular}

Resource: Field Research

The data above shows that the attitude of curious students is still very low (26\%). The curious attitude of the average male student $(17.65 \%)$ is lower than the female student $(30.30 \%)$. Based on these data it can be seen that the attitude of curiosity is related to the critical attitude of female students in each lecture. In other words, the attitude of curiosity becomes the capital towards the critical attitude of students.

\subsection{Open attitude and objective}

An open attitude can be seen from habits related to the ability of students to receive input, criticism, ideas or ideas from others and show a willingness to collaborate with others. While the objective attitude is reflected by the ability of students to do assignments under instructions and the maximum and recognition of weaknesses and mistakes made in completing assignments that have an impact on the acquisition of low grades. The survey results about open attitude can be seen in Table 3. below:

Tabel 3. Average of Open Attitude

\begin{tabular}{cccc}
\hline Gender & Never & Often & Constantly \\
\hline Male & 3 & 4 & 10 \\
Female & 5 & 8 & 20 \\
\hline
\end{tabular}

Resource: Field Research

Based on Table 3. above shows the level of open attitude is quite high both in male students $(58.82 \%)$ and women $(60.61 \%)$. Overall, the average open attitude of students who were respondents in the study was $60 \%$. The results of a survey of 50 students about objective attitudes can be seen from the following Table 4.

Table 4. Average of Objective Attitude

\begin{tabular}{cccc}
\hline Gender & Never & Often & Constantly \\
\hline Male & 2 & 3 & 12 \\
Female & 4 & 7 & 22 \\
\hline
\end{tabular}

Resource: Field Research

Data Table 4. above shows that the objective attitude of male student respondents is quite high at $70.59 \%$ while female students are $66.67 \%$. Overall, the average objective attitude of respondents was $68 \%$. Based on these data it can be said that an open attitude is related to the objective attitude of the respondents.

\subsection{Attitude to respect the work of others and attitude to defend the truth}

The attitude of respect for the work of others can be shown from the habit of not doing plagiarism and completing tasks with full integrity. The results of a survey of these attitudes can be seen in Table 5 below: 
Table 5. Average of Attitude to Respect the Work of Others

\begin{tabular}{cccc}
\hline Gender & Never & Often & Constantly \\
\hline Male & 3 & 4 & 10 \\
Female & 4 & 11 & 18 \\
\hline
\end{tabular}

Resource: Field Research

Table 5. above shows the respect of male respondents with gender toward the work of others by $58.82 \%$. While the same attitude towards female student respondents was $54.55 \%$. The overall attitude of student respect for the work of others reached an average of $56 \%$.

The survey results regarding courage to defend the truth about 50 students are shown in Table 6 below:

Table 6. Average of Attitude to Defend The Truth

\begin{tabular}{cccc}
\hline Gender & Never & Often & Constantly \\
\hline Male & 4 & 4 & 9 \\
Female & 10 & 12 & 14 \\
\hline
\end{tabular}

Resource: Field Research

Table 6. above reflects that $42.42 \%$ of female students dare to defend the truth and $52.94 \%$ of male students have the same attitude. Overall, $50 \%$ of the 50 respondents dared to defend the truth. The fact above illustrates that the attitude of respect for the work of others is influenced by the attitude of courage to defend the truth. In other words, the lower the attitude of respect for the work of others, the lower the attitude of courage to defend the truth.

Interesting questions that form part of the formulation of research problems are what factors influence academic culture among students. There are nine factors that can influence the development of academic culture including: appreciation of the opinions of others objectively, the habit of using rational and critical-analytical thinking with moral responsibility, reading habits, knowledge and insight, habits of researching and serving the public, habit of writing articles, papers, books, scientific discussion habits, teaching-learning processes, and good college management.

The first factor is respect for the opinions of others objectively developing academic culture. This factor is shown from several indicators, namely acceptance of input and criticism from other parties for their opinions, giving opinions to other people's views, accepting other people's ideas or ideas, and acknowledging mistakes and weaknesses in completing tasks. Based on observations outside and in teaching and learning activities against the indicators above, researchers see students rarely receive or give an appreciation (response) to the opinions of others objectively. Furthermore, the habit of rational and critical analytical thinking with moral responsibility becomes the second factor influencing the development of academic culture among students. Rational and analytical critical thinking is a habit that is shown by the following indicators: delivering statements (criticism) according to reality, doing the task according to instructions, not snooping, not doing plagiarism in completing the task, and doing the task to the maximum. Observations made on student indicators still rarely use rational and critical analytical thinking with moral responsibility.

Observations on reading habits, additional knowledge and insight are made by referring to the following indicators: Always read the lecture contract and course RPS taken, prepare 
yourself before the lecture begins by reading various sources related to the topics discussed, and reading good books that are not related to the topic discussed. Based on the results of observations of these indicators, researchers found reading habits, adding knowledge and insight are still rarely done. The assignment of CBR and CJR has not been able to improve students' reading habits because it is still considered to be a task rather than a necessity and there is an assumption among students that the CBR and CJR assignments are not examined to encourage students to simply duplicate the assignment.

The habit of researching and serving the community can be seen from the increasing involvement of students in research and dedication conducted by lecturers or can be seen through increased proposals for Student Student Creativity Program (PKM-P) and Community Service (PKM-M). Institutional policy since 2017 which requires involving students in research and community service activities by including the names of students in the proposal has succeeded in increasing student involvement in research and community service. Besides, mini-research assignments have also succeeded in increasing research activities and serving the community among student success in developing the habit of researching and serving the community was not as successful as developing writing habits. This is due to the lack of involvement of students in writing articles, books and the like. This can also be seen from the absence of books or articles that resulted from the published collaboration between lecturers and students.

Observation of teaching and learning activities is an important part of this research. Based on observations of all lecture activities (teaching and learning), it seems that lecturers are still the center of activities so it is not possible for the development of academic culture. The next factor is the habit of scientific discussion. The habit of discussion seems to be one of the favorite methods in classroom learning activities. However, the discussions carried out still could not help improve academic culture. The discussion was still going on just conveying the results of group work and question and answer that impressed formality. The last observation made was college management. Some indicators that are used as a basis for observing university management related to the development of academic culture are activities that support the development of academic culture from the level of study programs to tertiary institutions and policies that encourage the development of academic culture.

Based on observations, there are only a few activities from the level of the study program to university carried out to support or enhance academic culture among students. The activities carried out were impressed as being activities without regard to the quality or impact of the activities. Habitus is generally interpreted as a structure that exists in individuals to maintain their existence in social life. The structure is embedded in these individuals and later implemented in social life. Habitus then forms a relatively permanent trait in the individual. Habitus will shape the actions and behavior of individuals unconsciously.

The field or arena of social struggle refers to the social reality and structure of the individual living so that the condition of habitus gives a subjective value to the arena (field). Arena and habitus determine the materialistic and symbolic values of various forms of capital and individual conversion. While social capital is the number of resources, actual or virtual that gather in an individual or group because it has a long-lasting network of reciprocal introductions and recognition that is more or less institutionalized [6].

\section{Conclusion}


Each of the attitudes in academic culture does not stand alone or relate to one another. In other words, an attitude influences the other attitude, therefore an attitude development program cannot be separated or must become a unified program. A map of student academic culture helps us to see attitudes that are developing among students and can be used as a basis for making the policies needed to develop students. Attitudes in academic culture can be the character of students. Therefore the mapping of academic culture becomes very important to improve student character.

Acknowledgments. I would like to thank Rector of Universitas Negeri Medan for his kindness to give the team in this research to do the research. Great, thank also given to all students as a participant in this research for their cooperation.

\section{References}

[1] P. Pasaribu, W. Malau, T. Simarmata, and D. H. P. Simanjuntak, "Strategi Penerapan Enam Penugasan Pada Mata Kuliah Antropologi Perkotaan Di Prodi. Pendidikan Antropologi,” Buddayah J. Pendidik. Antropol., vol. 1, no. 2, pp. 162-167, 2017.

[2] D. N. Nikmah, "Implementasi budaya akademik dan sikap ilmiah mahasiswa," Manaj. Pendidik., vol. 24, no. 6, pp. 483-490, 2012.

[3] A. Masruroh and M. Mudzakkir, "Praktik Budaya Akademik Mahasiswa," Paradigma, vol. 1, no. 2, 2013.

[4] G. Ritzer, Sosiologi Ilmu Berparadigma Ganda. Jakarta: Grafindo Persada, 2010.

[5] D. H. P. Simanjuntak, P. Pasaribu, W. Malau, and T. Simarmata, "Penerapan Pembelajaran Kontekstual Untuk Meningkatkan Berpikir Kritis Mahasiswa Pada Mata Kuliah Antropologi Pariwisata," Buddayah J. Pendidik. Antropol., vol. 1, no. 2, pp. 124-131, 2017.

[6] P. Bourdieu, The Forms of Capital”, dalam J.Richardson, ed. Handbook of Theory and Research for the Sociology of Education. Westport, CT: 1986. 